ISSN 2614-2775 (Print)

Tahun 2021

ISSN 2621-8143 (Online)

\title{
LEARNING FOREHAND SERVICE BADMINTON USING TEACHING GAMES FOR UNDERSTANDING (TGFU) STUDENTS
}

\author{
Silvi Aryanti' ${ }^{1}$, Soleh Solahuddin ${ }^{2}$, Samsul Azhar ${ }^{3}$ \\ Universitas Sriwijaya ${ }^{1,2}$, Universitas Muhammadiyah Tangerang ${ }^{3}$ \\ silviaryanti@fkip.unsri.ac.id ${ }^{1}$, solehsolahuddin@fkip.unsri.ac.id ${ }^{2}$ \\ samsulazhar35@gmail.com ${ }^{3}$
}

\begin{abstract}
The purpose of this study was to improve learning for badminton services through teaching games for understanding (TGFU) in class IX.1 students of Senior High School 19 Palembang. This research is a Classroom Action Research. The subjects of the classroom action research were 32 students of class IX.1 totaling 32 people. This research starts from initial observation, action planning, action implementation, observation or monitoring (observation), reflection (reflection) on every action taken and evaluation. Initial observations were made to find out the problems that consisted when learning took place including learning outcomes in learning the badminton service material in three domains, namely the affective, cognitive, and psychomotor domains. The results of the pre-test research (preliminary data) were obtained in terms of the affective aspect classically said to be complete, because as many as 23 students (71.87\%) had fulfilled the minimum completeness criteria, from the cognitive realm as many as 29 students (90.63\%) were very good, and the average score was The class average for the incomplete psychomotor domain was 19 students with a presentation of 59.38 (insufficient). Therefore, cycle I was carried out to improve the average score in the psychomotor domain, the results obtained were a percentage of 84.38 (good category), so that classically the students had completed in the psychomotor domain. This shows that the results of the psychomotor aspect have increased. The implication of this research is learning badminton service can be increased through the TGFU learning model.
\end{abstract}

Keywords: service, badminton, TGFU, Classroom Action Research

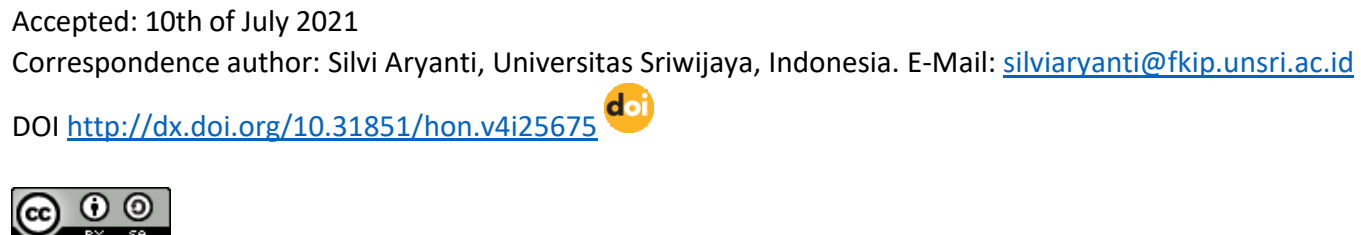

Jurnal Halaman Olahraga Nusantara licensed under a Creative Commons Attribution-ShareAlike 4.0 International License. 


\section{INTRODUCTION}

Education in schools is an interaction between teachers and students in a learning process. Through education, there is a process of knowledge transfer by the teacher so that the potential of students can be developed. Education has an element of learning between teachers and students. Learning is a learning activity of teachers and students that can be modified intentionally with various conditions. It is aimed at achieving a learning goal (Hardini and Puspitasari, 2012). Corey (Syaiful Sagala, 2011) the concept of learning, namely environmental management is the intentional participation of certain behaviors in special conditions or resulting in responses to certain situations, so that learning is a special part of education.

Learning Physical Education, Sports and Health is found in Elementary Schools, Junior High Schools, and High Schools. Physical education is an educational process that has elements of physical activity. Physical education aims to provide change and quality of a person from the cognitive, affective and psychomotor aspects. Aryanti (2018) Physical Education, Sports and Health has a goal for students to do it systematically based on the values of faith and piety. Juliantine, et al (2015) when physical education learning objectives are achieved, then physical education teachers must have good knowledge and understanding. PJOK learning in education units uses the 2013 curriculum. According to Zaini (2015) the development of student competencies in the 2013 curriculum can be further analyzed and the demands of teachers to be more creative and innovative in learning. This is because the teacher is able to do everything, thus helping students to develop. Mulyasa (2014) emphasizes character education in the 2013 curriculum, especially at the basic level which will be used as the foundation for the next level. With the development of the 2013 curriculum at the education level, it is hoped that the nation will have a selling point that can be offered to other nations in the world. character-based and competencybased. 


\section{Accredited}

One of the physical education learning materials is a small ball game (badminton service). Basic competence in small ball games in class IX.1 Junior High School Number 9 Palembang 3.2. Understanding the concept of skill variations and combinations, as well as modified rules in small ball games, 4.2. Practice variations and combinations of skills into small ball games in a smooth, controlled, and coordinated manner (Okilanda et al., 2021). Based on the results of observations when learning badminton services in the classroom, it has not been carried out well. It can be seen that students when participating in the implementation of learning in the classroom do not look so enthusiastic. The learning model used when learning is monotonous, less varied so that students look less interested. Most students wait their turn, and are afraid to try to practice badminton serve.

Based on the problems during the learning process of badminton service material both in class and in the field, the right learning model is needed. A good learning model can help teachers achieve learning goals. Bambang (2018) Human resources can be improved through the learning process at school. Quality improvement is supported by the presence of teachers who provide material in the process learn how to teach.Ruslan (2019) Ruslan (2019) Teachers must have the ability to be able to develop learning. This is aimed at increasing success so that learning objectives are achieved. Fathurrohman (2015) in choosing the right learning model, the condition of the students, the nature of the teaching materials, the available media facilities, and the condition of the teacher must be considered.

The selection of the learning model chosen by the teacher, the nature of the material to be studied, the objectives (competencies) greatly affect so that the learning objectives will be achieved. Therefore, the learning model used in this study is Teaching Games for Understanding (TGFU). Pujianto (2014), Teaching Games for Understanding (TGFU) is a physical education learning approach for children to be introduced to understand sports through the basic concepts of playing. Century (2020) 


\section{Accredited}

model TGFU as an alternative that focuses on the cognitive development and skills of students through decision making during games. Gil-Arias (2020) the use of the TGfU learning model positions the teacher as a facilitator. while the teacher not only gives students the opportunity to make decisions independently of the teacher in small and/or modified/conditioned games, using questions and debating ideas. Students are guided, facilitated, and problem solving capacity is strengthened. Miller (2015) The TGfU learning model is when learning complex decision-making and technical execution skills in games developed environment Barba-Martín (2020) based on the ideas of experts, this is what has created a teaching game using TGfU. Iqbal (2017) research results show that TGFU learning model through the close-open learning stages of rounders playing skills can be improved in fifth grade students at SDN Cigondewah 3, Bandung Regency, for the 2017/2018 Academic Year. Harvey (2020) emphasizes the need for a pedagogical model such as the TGFU. Aims to improve student capacity in evaluating game situations and developing tactical reasoning. According to Mitchell, Oslin and Griffin (in Pambudi, 2010) the characteristics of the TGFU learning model in game management are that each game form has its own characteristics and characteristics. It gives players a different sense of pleasure and is divided into 4 game classifications, namely target games, net games, fielding games, and invasion games.

The classification of the TGFU model on badminton service material is included in the net game. The urgency of this research is the use of the TGFU learning model when providing badminton service material to class IX.1 students of Junior High School Number 9 Palembang. It aims to make learning more interesting and students' understanding can be improved. Based on the existing problems, improvements are needed to achieve badminton service learning. Therefore, the authors are interested in conducting classroom action research on improving badminton service learning through the TGFU approach. 


\section{METHOD}

This research is a Classroom Action Research, which is to apply the Teaching Games for Understanding (TGFU) learning model effectively and efficiently in teaching and learning activities for badminton service materials. The subjects of this study were students of class IX.1 Junior High School Number 9 Palembang totaling 32 students.

The implementation of classroom action research in this study was carried out in a cycle form as shown below:

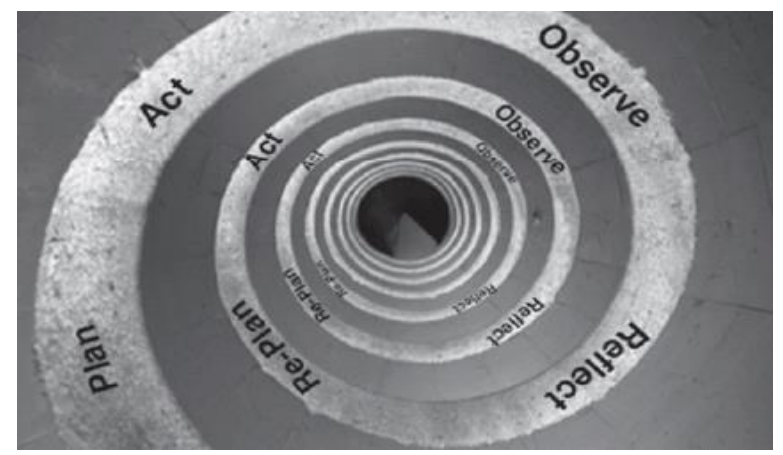

Figure 1. Kemmis and McTaggart . Model Action Research

Source: Kemmiset.al. The Action Research Planner (Singapore: Springer Science, 2014), h. 19

This research starts from initial observation, action planning, action implementation, observation or monitoring (observation), reflection (reflection) on every action taken and evaluation.

\section{RESULT AND DISCUSSION}

Implementation per cycle aims to improve learning, if one cycle has not shown signs of problem solving towards improvement (improvement), research activities are continued in the second cycle, and so on. The aspect observed in each cycle is the activity when learning badminton service techniques for class IX.1 
Jendral A. Yani Street Lorong Gotong Royong 9/10 Ulu Palembang South Sumatera

email jurnal: jurnalhon@univpgri-palembang.ac.id situs web: http://www.univpgri-palembang.ac.id

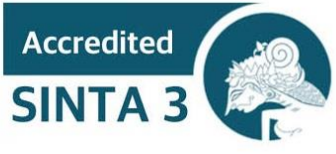

students of Junior High School Number 9 Palembang with the application of the badminton service learning model through games. The steps in this research start from initial observation, action planning, action implementation, observation or monitoring (observation), reflection (reflection) on each action taken and evaluation. The following is an explanation of each activity step in classroom action research:

\section{Preliminary Observation Results}

Initial observations were made to find out the problems that consisted during learning which included learning outcomes in learning the badminton service material in three domains, namely the affective, cognitive, and psychomotor domains. Initial observations that have been made obtained the following results:

The average value of the affective, cognitive and psychomotor domains with the assessments that have been observed during the learning in the first cycle, shows the assessment as follows.

Table 1. Results of observation of attitudes (affective) at the time of badminton service

\begin{tabular}{cclc}
\hline Value & Total students & Category & Percentage \\
\hline $86-100$ & 5 & Very good & 15,62 \\
$71,00-85,99$ & 18 & Good & 56,25 \\
$56,00-70,99$ & 9 & Enough & 28,13 \\
$41,00-55,99$ & 0 & Less & 0 \\
$<40,99$ & 0 & Very less & 0 \\
\hline
\end{tabular}

Based on the data above, it can be seen that the results of the attitude when following the down services lesson were in the very good category of 5 students (15.62\%), good category 18 students (56.25\%) and sufficient category 9 students. Classically it is said to be complete, because as many as 23 students (71.87\%) have met the minimum completeness criteria. 
Jendral A. Yani Street Lorong Gotong Royong 9/10 Ulu Palembang South Sumatera

email jurnal: jurnalhon@univpgri-palembang.ac.id email jurnal: jurnalhon@univpgri-palembang.ac.id
situs web: http://www.univpgri-palembang.ac.id

\section{Accredited}

SINTA 3

Table 2. The results of the assessment of the knowledge (cognitive) test of badminton

\begin{tabular}{cclc}
\multicolumn{4}{c}{ services } \\
\hline Value & Total students & \multicolumn{1}{c}{ Category } & Percentage \\
\hline $86-100$ & 10 & Very good & 31,25 \\
$71,00-85,99$ & 19 & Good & 59,38 \\
$56,00-70,99$ & 3 & Enough & 9,37 \\
$41,00-55,99$ & 0 & Less & 0 \\
$<40,99$ & 0 & Very less & 0 \\
\hline
\end{tabular}

The results of the assessment of the badminton service knowledge test for grade IX.1 students obtained 10 students (31.25\%) in the very good category, 19 students $(59.38 \%)$ in the good category, and 3 students $(9.37 \%)$ in the moderate category. Classically, students are said to be complete in the realm of knowledge with a presentation of 90.63 .

Table 3. Badminton service skill test results

\begin{tabular}{cclc}
\hline Value & Total students & \multicolumn{1}{c}{ Category } & Percentage \\
\hline $86-100$ & 2 & Very good & 6,25 \\
$71,00-85,99$ & 5 & Good & 15,62 \\
$56,00-70,99$ & 6 & Enough & 18,75 \\
$41,00-55,99$ & 19 & Less & 59,38 \\
$<40,99$ & 0 & Very less & 0 \\
\hline
\end{tabular}

Based on this data, it was found that students on the badminton service skills test who passed the Minimum Completeness Criteria were in the very good category, namely 2 students $(6.25 \%)$, in the good category, namely 5 students $(15.62 \%)$, sufficient category amounted to 6 people $(18,75)$. Classically, learning can be said to be incomplete, totaling 19 people (59.38\%).

The results of observations in the first cycle that have been obtained, show that the average value of the class in the affective domain of students reaches a percentage of 71.87 (good), the class average value for the cognitive domain reaches 
Jendral A. Yani Street Lorong Gotong Royong 9/10 Ulu Palembang South Sumatera

email jurnal: jurnalhon@univpgri-palembang.ac.id situs web: http://www.univpgri-palembang.ac.id

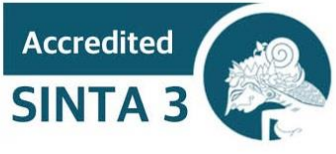

a presentation of 90.63 (very good), and the average class for the unfinished psychomotor domain is 19 students with a presentation of 59.38 (less).

The results of the qualification for the acquisition of the class average score for the affective domain are in the good category, so there is no need for re-emphasis in the next stage of learning. The qualification of the class average score for the cognitive or knowledge domain is very good. The qualification of the class average score in the psychomotor domain is included in the poor category, so it is necessary to take action to improve students' ability to carry out badminton services.

The learning of badminton service material for class IX.1 students of Junior High School Number 9 Palembang which has been ongoing has not yet entered the indicator of classical learning mastery achievement. This is so that there is a learning action to achieve the achievement indicator target.

\section{Cycle I Research Results}

In the psychomotor domain, it was obtained that it was lacking, so it was necessary to take action in cycle I. Based on the results of initial observations, it was found that the average score of class IX.1 students of Junior High School Number 9 Palembang was badminton service material. The following are the results of the badminton serve skills test after the action.

Table 4. Skills Test Results Badminton Service After Action

\begin{tabular}{cclc}
\hline Value & Total Students & \multicolumn{1}{c}{ Category } & Percentage \\
\hline $86-100$ & 8 & Very good & 25 \\
$71,00-85,99$ & 19 & Good & 59,38 \\
$56,00-70,99$ & 3 & Enough & 9,37 \\
$41,00-55,99$ & 2 & Less & 6,25 \\
$<40,99$ & 0 & Very less & 0 \\
\hline
\end{tabular}




\section{Accredited}

After being given the first cycle of student action on the badminton service skills test using the TGFU learning model, it was found that 8 students with a percentage of 25 were included in the very good category, 19 students with a percentage of 59.38 were included in the good category, 3 students with a percentage of 9.37 were included in the enough category, and 2 students with a percentage of 6.25 are included in the less category.

\section{DISCUSSION}

The application of the TGFU learning model, from the beginning, students are made to learn game appreciation and tactical awareness (Kinnerk, Harvey, MacDonncha, \& Lyons, 2018). Gil-Arias (2020) the application of the TGFU learning model by teachers, a learning environment that is supportive, inclusive, and fair all students have the opportunity to be involved, have fun and social interaction in physical education lessons. Arias (2020) Implementation of TGfU model during student learning must be physically and mentally involved in every task, play active role in communicating with friends. Therefore, automatically students' knowledge is built supported by the design of the learning environment by the teacher.

Munadi (2010) Changes that include cognitive, affective and psychomotor aspects are the essence of student learning outcomes. Benjamin S. Bloom in Asep and Abdul Haris (2016), learning outcomes include these three domains, namely cognitive, affective and psychomotor. The results of this study consist of three domains, namely affective, cognitive and psychomotor.

The results of the pretest (initial data) were obtained from the affective aspect that students had completed, because 23 students $(71.87 \%)$ so that the minimum completeness criteria were achieved, in the cognitive domain the presentation obtained was 90.63 (very good), and the average the average class for the unfinished psychomotor domain is 19 people $(59.38 \%)$ in the less category. It is necessary to do 


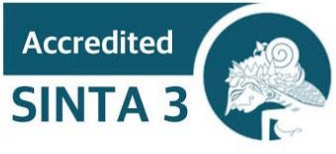

the first cycle aimed at improving the average score in the psychomotor domain of badminton services for grade IX.1 students. The results obtained after taking action on the psychomotor aspect, namely the percentage of 84.38 (good category), so that students classically have completed in the psychomotor realm. This shows an increase in results from the psychomotor aspect, so there is no need to do cycle II. This is in line with previous research by Jaya (2019), the results of the study obtained that there was an increase in the value of student cooperation. The results of the study are expected to provide information to teachers and practitioners of early childhood sports development, for playing skills and student cooperation through the application of TGFU can be improved. Chan (2018) the results of classroom action research show that by using the Teaching Games for Understanding (TGFU) approach, students are more active, happy and interested in participating in volleyball learning, student learning outcomes with a class average of $82.6 \%$ (Very Good) are improved. , the better passing down is done by students. Thus, the Teaching Games for Understanding (TGFU) approach can improve the ability of passing down in volleyball for class VIII students at Junior High School Number 11 Muaro Jambi.

Based on the research results and relevant research results, the TGFU learning model can improve student learning outcomes. The increase that occurred, especially in terms of the psychomotor aspect of serving badminton forehand. Therefore, it can facilitate students in learning and improve learning outcomes.

\section{CONCLUSION}

The implementation of the Teaching Games for Understanding (TGFU) learning model makes the psychomotor abilities of class IX.1 students of Junior High School Number 9 Palembang improve the material for badminton services. This can be seen from the learning outcomes of students who have achieved minimal mastery. Shows that it is not necessary to continue in the second cycle stage. 
Jendral A. Yani Street Lorong Gotong Royong 9/10 Ulu Palembang South Sumatera

email jurnal: jurnalhon@univpgri-palembang.ac.id situs web: http://www.univpgri-palembang.ac.id

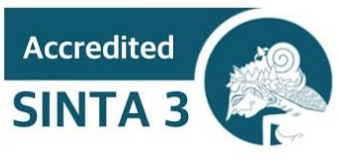

\section{REFERENCES}

Abad, M.T.; Collado-Mateo, D.; Fernández-Espínola, C.; Castillo, E.; Giménez, F.J. Effects of Teaching Games on Decision Making and Skill Execution: A Systematic Review and Meta-Analysis. Int. J. Environ. Res. Public Health 2020, 17, 505 .

Adi, S., \& Fathoni, A. F. (2019, November). Development of Learning Model Based on Blended Learning in Sports School. In 5th International Conference on Physical Education, Sport, and Health (ACPES 19) (pp. 8-12). Atlantis Press.

Arifin, Zainal. Evaluasi Pembelajaran: Prinsip, Teknik, dan Prosedur.Bandung: Remaja Rosdakarya, 2016.

Arias-Estero, J. L., Jaquero, P., Martínez-López, A. N., \& Morales-Belando, M. T. (2020). Effects of two TGfU lessons period on game performance, knowledge and psychosocial variables in elementary physical education. International journal of environmental research and public health, 17(10), 3378.

Aryanti, S., Victorian, A. R., \& Yusfi, H. (2018). Pengembangan Teknik Pembelajaran Servis Bulutangkis bagi Siswa Putra Sekolah Menengah Atas. Sebatik, 22(2), 181-187.

Barba-Martín, R. A., Bores-García, D., Hortigüela-Alcalá, D., \& González-Calvo, G. (2020). The application of the teaching games for understanding in physical education. Systematic review of the last six years. International journal of environmental research and public health, 17(9), 3330.

Chan, F., \& Indrayeni, Y. (2018). Meningkatkan Kemampuan Passing Bawah dalam Permainan Bola Voli Melalui Pendekatan Tgfu Pada Siswi Kelas VIII SMP Negeri 11 Muaro Jambi. Journal Physical Education, Health and Recreation, 2(2), 186-197.

Fathurrohman, M. (2015). Model-Model Pembelajaran. Jogjakarta: Ar-Ruzz Media.

Gil-Arias, A., Harvey, S., García-Herreros, F., González-Víllora, S., Práxedes, A., \& Moreno, A. (2020). Effect of a hybrid teaching games for understanding/sport education unit on elementary students' self-determined motivation in physical education. European Physical Education Review, 1356336X20950174. 
Jendral A. Yani Street Lorong Gotong Royong 9/10 Ulu Palembang South Sumatera

email jurnal: jurnalhon@univpgri-palembang.ac.id situs web: http://www.univpgri-palembang.ac.id

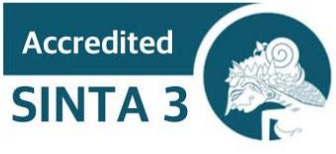

Harvey, S., Gil-Arias, A., \& Claver, F. (2020). Effects of Teaching Games for Understanding on tactical knowledge development in middle school physical education. Journal of Physical Education and Sport, 20(3), 1369-1379.

Hardini, Isriani dan Dewi Puspitasari. 2012. Strategi Pembelajaran Terpadu (Teori, Konsep, \& Implementasi). Yogyakarta: Familia.

Hermansah, B. (2018). Upaya Meningkatkan Hasil Belajar Jump Shoot Dalam Permainan Bola Tangan Dengan Gaya Mengajar Resiprokal Pada Siswa Kelas Ix Smp N 5 Indralaya Utara Tahun Ajaran 2017/2018. Halaman Olahraga Nusantara (Jurnal Ilmu Keolahragaan), 1(2), 249-262.

Hutapea, R. H. (2019). Instrumen Evaluasi Non-Tes dalam Penilaian Hasil Belajar Ranah Afektif dan Psikomotorik. BIA': Jurnal Teologi dan Pendidikan Kristen Kontekstual, 2(2), 151-165.

Iqbal, M. (2017). Penerapan Model Pembelajaran Tgfu (Teahing Game For Understanding) Pada Permainan Rounders Melalui Pentahapan Pembelajaran Closed-Open Skill: Penelitian Tindakan Kelas pada Siswa kelas 5 SDN Cigondewah $3 \mathrm{Kab}$. Bandung (Doctoral dissertation, Universitas Pendidikan Indonesia).

Jaya, B. S. Penerapan Model Teaching Games for Understanding dalam Permainan Sepakbola di Sekolah Dasar. TEGAR: Journal of Teaching Physical Education in Elementary School, 3(1), 35-38.

Juliantine, dkk. (2015). Model-Model Pembelajaran dalam Pendidikan Jasmani. Bandung: CV. Bintang Warliartika.

Kemmis, S., McTaggart, R., \& Nixon, R. (2014). The Action Resesarch Planner (ISBN 978-9). Singapore: Springer.

Kinnerk, P., Harvey, S., MacDonncha, C., \& Lyons, M. (2018). A review of the game-based approaches to coaching literature in competitive team sport settings. Quest, 70(4), 401-418.

Miller, A. Games Centered Approaches in Teaching Children \& Adolescents: Systematic Review of Associated Student Outcomes. J. Teach. Phys. Educ. 2015, 34, 36-58. 
Jendral A. Yani Street Lorong Gotong Royong 9/10 Ulu Palembang South Sumatera

email jurnal: jurnalhon@univpgri-palembang.ac.id situs web: http://www.univpgri-palembang.ac.id

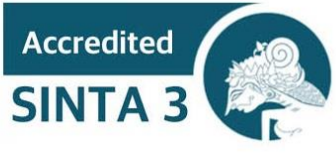

Mulyasa. (2014). Pengembangan dan Implementasi Kurikulum 2013. Bandung: PT Remaja Rosdakarya.

Munadi, Yudhi. (2010). Media pembelajaran Jakarta : Gaung persada (GP) press.

Pambudi, A. F. (2010). Target Games: Sebuah Pengembangan Konsep Diri Melalui Pembelajaran Pendidikan Jasmani. Jurnal Pendidikan Jasmani Indonesia, 7(2).

Paramitha, S. T., \& Anggara, L. E. (2018). Revitalisasi pendidikan jasmani untuk anak usia dini melalui penerapan model bermain edukatif berbasis alam. Jurnal Pendidikan Jasmani dan Olahraga, 3(1), 41-51.

Pujianto, A. (2014). Persepsi Guru Pendidikan Jasmani terhadap Model Teaching Games For Understanding (TGFU). Journal of Physical Education Health and Sport, 1(2), 86-92.

Ruslan, R., \& Huda, M. S. (2019). Penerapan Metode Bermain Dalam Meningkatkan Hasil Belajar Guling Depan (Forward Roll). Halaman Olahraga Nusantara (Jurnal Ilmu Keolahragaan), 2(1), 10-20.

Sagala, Syaiful. 2011. Supervisi Pembelajaran dalam Profesi Pendidikan. Bandung: Alfabeta.

Okilanda, A., Dlis, F., Humaid, H., Putra, D. D., Arisman, A., \& Muslimin, M. (2021). Defense Warm-Up Exercise Material for 13-Age Athlete Using Video Technology in Covid-19 Era. International Journal of Human Movement and Sports Sciences, 9(4), 629-634. https://doi.org/10.13189/saj.2021.090404 